\title{
WATER COLUMN PROFILES OF DISSOLVED INORGANIC RADIOCARBON FOR THE KUROSHIO REGION, OFFSHORE OF THE SOUTHERN JAPANESE COAST
}

\author{
Tatsuya Tsuboi ${ }^{1} \cdot$ Hiroshi Iwata $^{2} \cdot$ Hideki Wada $^{2,3} \cdot$ Hiroyuki Matsuzaki $^{4} \cdot$ Rumi Sohrin $^{2} \bullet$ \\ Yutaka Hiroe $^{5}$ Tadafumi Ichikawa ${ }^{5}$ Kiyotaka Hidaka $^{5} \cdot$ Tomoo Watanabe $^{5}$
}

\begin{abstract}
We present the water column profiles (surface to $2000 \mathrm{~m}$ depth) for dissolved inorganic radiocarbon $\left({ }^{14} \mathrm{C}_{\mathrm{DIC}}\right)$ from 2 stations in the Kuroshio region including the Kuroshio large meander (LM) of 2004-2005. Surprisingly, the $\Delta^{14} \mathrm{C}_{\mathrm{DIC}}$ value varied up to $125 \%$ in the intermediate layer, especially near $600 \mathrm{~m}$ depth. In addition, the $\Delta^{14} \mathrm{C}_{\mathrm{DIC}}$ value was approximately $-150 \%$ at $200 \mathrm{~m}$ depth at the northern station of Kuroshio in August 2005 . This value is $\sim 100 \%$ less than other $\Delta \Delta^{14} \mathrm{C}_{\mathrm{DIC}}$ values for the same depth. In comparison, the $\Delta^{14} \mathrm{C}_{\mathrm{DIC}}$ water column profiles for the southern station of Kuroshio and GEOSECS station 224 decrease down to $600 \mathrm{~m}$ depth and were similar below $600 \mathrm{~m}$ depth. Our results suggest that strong upwelling associated with the Kuroshio LM has a powerful influence on the $\Delta{ }^{14} \mathrm{C}_{\mathrm{DIC}}$ water column profiles in the study region.
\end{abstract}

\section{INTRODUCTION}

\section{Background}

Radiocarbon $\left({ }^{14} \mathrm{C}\right)$ measurements of dissolved inorganic carbon (DIC) have been a key tool in the research of oceanic carbon cycling and global-regional seawater circulation. Since systematic measurements of dissolved inorganic radiocarbon $\left({ }^{14} \mathrm{C}_{\mathrm{DIC}}\right)$ began in the 1960s, 2 major global geochemical surveys have been carried out in the Pacific Ocean. The first was the Geochemical Ocean Section Study (GEOSECS) Pacific expedition during the 1970s. The second is the World Ocean Circulation Experiment (WOCE), which has been underway since the 1990s. Stuiver et al. (1983) and Broecker (1987) reported deep-water circulation based on the ${ }^{14} \mathrm{C}_{\text {DIC }}$ data sets of the GEOSECS. In the past decade, many studies on processes of penetration and advection have been carried out. Kumamoto et al. (2002), for example, reported bomb-produced ${ }^{14} \mathrm{C}$ penetration in the northwestern North Pacific Ocean and attributed this to bomb-produced ${ }^{14} \mathrm{C}$ accumulation in the intermediate water of the Kuroshio region. Povinec et al. (2004) reported bomb-produced ${ }^{14} \mathrm{C}$ penetration in the southwestern North Pacific Ocean, and revealed that bomb-produced ${ }^{14} \mathrm{C}$ had been advected northward by the Kuroshio and was then stored in the intermediate layer (between $\sim 200$ and $800 \mathrm{~m}$ depth). Similar studies were carried out in the equatorial Atlantic Ocean (Broecker et al. 1978), the Pacific Ocean (Stuiver et al. 1996; Aramaki et al. 2001; Druffel et al. 2008), the Indian Ocean (Bard et al. 1989; Somayajulu et al. 1999; Bhushan et al. 2000, 2003), and the Arabian Sea (Bhushan et al. 2003, 2008). Druffel et al. (2008) reported observations of ${ }^{14} \mathrm{C}_{\text {DIC }}$ variations for the last several decades. In addition, an estimation of upwelling ratios was calculated using bomb-produced ${ }^{14} \mathrm{C}$ for the Arabian Sea (Bhushan et al. 2008). These and other studies have demonstrated the important contribution in oceanographic research of ${ }^{14} \mathrm{C}_{\mathrm{DIC}}$ as a tracer of transport and mixing of water masses.

Here, we present the ${ }^{14} \mathrm{C}_{\mathrm{DIC}}$ vertical profiles (down to $2000 \mathrm{~m}$ depth) for 2 sites in the Kuroshio region, offshore of the Japanese southern coast during 2005 to 2006. From July 2004 to August 2005 , the Kuroshio formed a large meander (LM) in its flow pattern. We attribute the observed significant variation of ${ }^{14} \mathrm{C}_{\mathrm{DIC}}$ values in the study area to sampling during the Kuroshio LM of July 2004-August 2005. Furthermore, we discuss the relationship between ${ }^{14} \mathrm{C}_{\mathrm{DIC}}$ and physical oceano-

\footnotetext{
${ }^{1}$ Graduate School of Science, Shizuoka University, 836 Oya, Suruga-Ku, Shizuoka 422-8529, Japan.

${ }^{2}$ Institute of Geosciences, Shizuoka University, 836 Oya, Suruga-Ku, Shizuoka 422-8529, Japan.

${ }^{3}$ Corresponding author. Email: sehwada@ipc.shizuoka.ac.jp.

${ }^{4}$ Research Center for Nuclear Science and Tech., University of Tokyo, 2-11-16 Yayoi, Bunkyo-Ku, Tokyo 113-0032, Japan.

${ }^{5}$ National Research Institute of Fisheries Science, Fisheries Research Agency, 2-12-4 Fukuura, Kanazawa-Ku, Yokohama 236-8648, Japan.
} 
graphic data. We suggest that the ${ }^{14} \mathrm{C}_{\mathrm{DIC}}$ data may be useful as a proxy of upwelling intensity and mixing processes.

\section{Oceanography of the Western North Pacific Ocean}

Figure 1 presents the main surface current patterns of the western North Pacific Ocean. The Kuroshio and Oyashio currents are western boundary currents in the subtropical and subarctic circulations of the western North Pacific Ocean, respectively. The subtropical circulation includes a large anticyclonic surface current that incorporates the Kuroshio. The Kuroshio is a warm current that originates near the Philippines. It flows offshore from the southern Japanese coast through the Tokara Channel. The subarctic circulation includes a cyclonic surface current that incorporates the Oyashio.

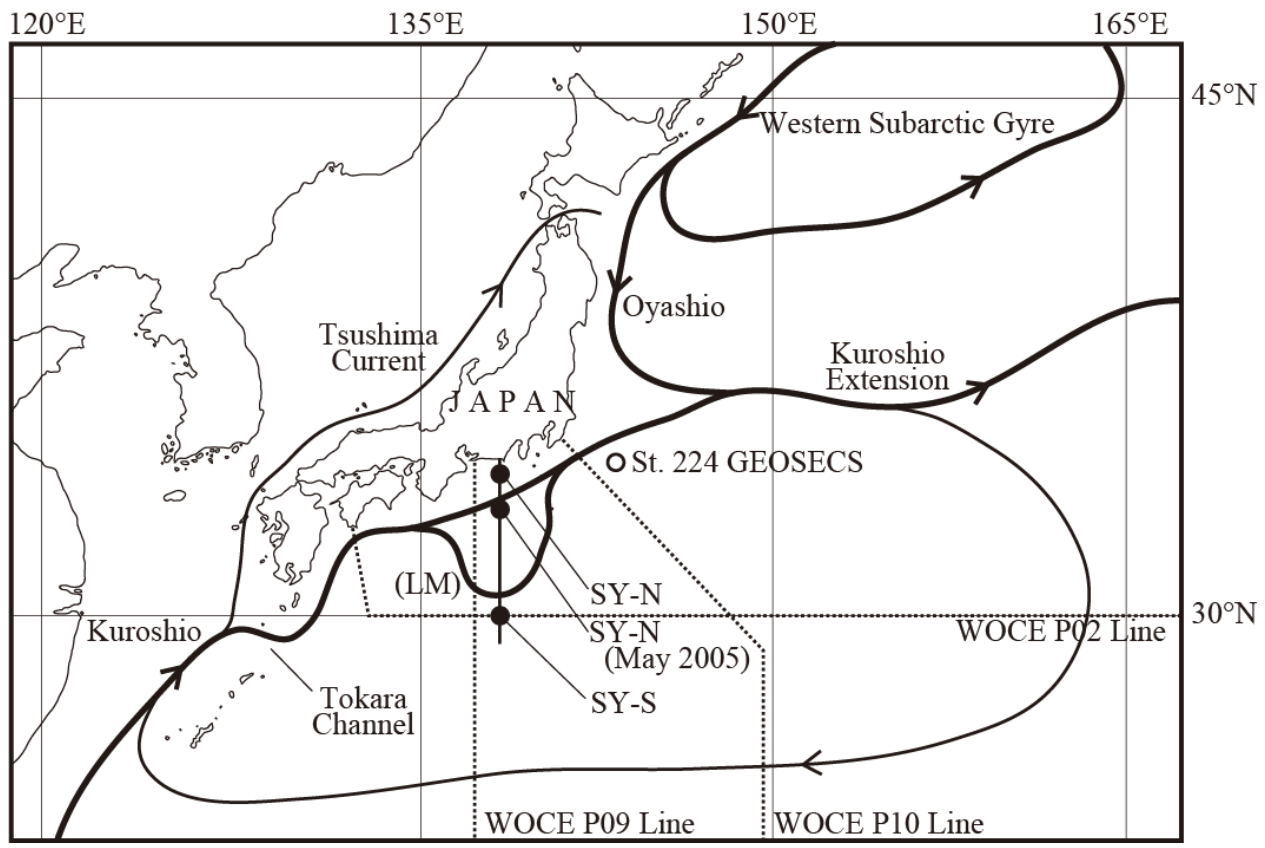

Figure 1 Map of the major surface current patterns of the western Pacific Ocean. The sampling stations are identified by small black circles (SY-S and SY-N). GEOSECS station 224 (Östlund and Stuiver 1980) and several other sampling cruises (WOCE lines P02, P09, and P10; CCHDO 2011) are identified by an open circle and black lines, respectively.

The major water masses in the western North Pacific are North Pacific Intermediate Water (NPIW), North Pacific Deep Water (NPDW), North Pacific Subtropical Mode Water (NPSTMW), and North Pacific Tropical Water (NPTW). NPIW is in large part responsible for the transport of subarctic-origin water to the subtropical zone of the North Pacific. NPIW is formed by mixing of waters in the region of the Kuroshio and Oyashio currents, and enters into the North Pacific subtropical gyre (Talley 1993). This subtropical gyre is anticyclonic, and NPIW exists between 300 and $800 \mathrm{~m}$ depth (You 2003). NPIW is characterized by a minimum salinity layer at $26.8 \sigma_{\theta}$ (where $\sigma_{\theta}$ is the potential density anomaly and $\sigma_{\theta}$ is equal to $1000 \times$ the potential density -1000$)$ (Reid 1965).

The Kuroshio greatly influences the oceanic structure of the southwestern North Pacific including the present study area. The Kuroshio has 2 flow patterns off the southern Japanese coast: (1) the large meander (LM) and (2) the non-large meander (NLM) (Stommel and Yoshida 1972; Kawabe 
1985, 1995, 2005). During the term of the LM, the Kuroshio flows southward from the southern coast of Japan.

Water column $\Delta^{14} \mathrm{C}_{\mathrm{DIC}}$ profiles for the Kuroshio region were determined from seawater samples collected as a part of the international GEOSECS Pacific expedition and the WOCE. Seawater sampling at GEOSECS station 224 was carried out in October 1973 (Östlund and Stuiver 1980) (Figure 1). Since the 1990s, seawater sampling has been carried out along WOCE lines P02 (JuneJuly 2004), P09 (July-August 1994), and P10 (October-November 1993) (CCHDO 2011) (Figure 1). These sampling efforts were carried out during the Kuroshio NLM term (Yoshida et al. 2006; Sugisaki et al. 2010). Horibe and Gamo (1980) reported $2 \Delta^{14} C_{\text {DIC }}$ measurements for the cold water mass during the LM term from 1975 to 1980 . However, the assessment of ${ }^{14} \mathrm{C}_{\mathrm{DIC}}$ variation in the region requires additional investigations.

\section{MATERIALS AND METHODS}

\section{Seawater Sampling}

Conductivity-temperature-depth (CTD) profiler observations and seawater sample collections were carried out between May 2005 and May 2006, on board the Research Vessel (R/V) Soyo-Maru of the National Research Institute of Fisheries Science, Fisheries Research Agency (NRIFS-FRA), Japan.

Seawater samples for ${ }^{14} \mathrm{C}$ measurements were collected at the southern (SY-S at $30^{\circ} \mathrm{N}, 138^{\circ} \mathrm{E}$ ) and northern (SY-N at $33^{\circ} \mathrm{N}, 138^{\circ} \mathrm{E}$ in May 2005 or at $34^{\circ} \mathrm{N}, 138^{\circ} \mathrm{E}$, based on the location of the Kuroshio) stations in the Kuroshio region. Stations SY-S and SY-N are comparable to stations C3000 and C3400 (C3300; May 2005), which are time-series stations on the O-Line (Sugisaki et al. 2010). Seawater was sampled at depths of 200, 400, 600, 1000, and $2000 \mathrm{~m}$.

Seawater samples were collected at each station with Niskin ${ }^{\mathrm{TM}}$ 2-L bottles mounted on a Rosette sampler. This procedure is described by Tsuchiya and Wada (2002). In brief, $250-\mathrm{mL}$ glass bottles were filled with argon gas to prevent contamination by atmospheric $\mathrm{CO}_{2}$. The bottles were filled with $\sim 150 \mathrm{~mL}$ of seawater using silicone tubing. Then, each sample was doped with $\sim 0.1 \mathrm{~mL}$ of saturated mercury (II) chloride $\left(\mathrm{HgCl}_{2}\right)$ solution to prevent biological activity (e.g. photosynthesis and respiration) and stored in a cool, dark place.

\section{Sample Preparation and ${ }^{14} \mathrm{C}$ Analysis}

Extraction of $\mathrm{CO}_{2}$ gas and preparation of graphite for all samples was carried out in the Department of Geosciences, Shizuoka University. Seawater dissolved inorganic carbon (DIC) was extracted as $\mathrm{CO}_{2}$ gas using the vacuum extraction method presented by Tsuchiya and Wada (2002). In brief, each seawater sample was acidified with $5 \mathrm{~mL}$ of $85 \%$ orthophosphoric acid. The evolved $\mathrm{CO}_{2}$ gas was collected using a liquid nitrogen trap $\left(-196^{\circ} \mathrm{C}\right)$. In this process, all of the extracted gas was passed through a chilled n-pentane slush (about $-130^{\circ} \mathrm{C}$ ) to completely remove any water vapor. Finally, purified $\mathrm{CO}_{2}$ samples were stored in 6-mm glass tubes $\left(\right.$ Pyrex $\left.^{\circledR}\right)$.

Carbon dioxide samples were reduced to graphite on iron powder using pure hydrogen gas at $650{ }^{\circ} \mathrm{C}$ for $4 \mathrm{hr}$, following the method of graphitization described by Kitagawa et al. (1993). The graphite samples were pressed into targets for ${ }^{14} \mathrm{C}$ measurement by accelerator mass spectrometry (AMS).

We used the National Institute of Standard and Technology (NIST) oxalic acid powder standard (SRM 4990c). The standard reference material and the appropriate amount of copper oxide powder were placed into a quartz tube, which was vacuum-sealed. The quartz tube was heated at $850^{\circ} \mathrm{C}$ for 
$2 \mathrm{hr}$ in a ceramic tubular furnace. The standard reference material was oxidized to form $\mathrm{CO}_{2}$ gas, which was then reduced to graphite using the same procedure as described above for the samples.

We used SP2 graphite (Nippon Carbon Co., Ltd.) produced from purified coal as a background sample. The SP2 carbon and vanadium pentoxide powder were heated at $500{ }^{\circ} \mathrm{C}$ for $0.5 \mathrm{hr}$ in a ceramic tubular furnace to remove any surficial contamination. Then, the SP2 carbon and vanadium oxide powder were vacuum-sealed in a quartz tube and heated at $1000^{\circ} \mathrm{C}$ for $2 \mathrm{hr}$. The evolved $\mathrm{CO}_{2}$ gas was reduced to graphite using the same procedure as described above for the samples.

The ${ }^{14} \mathrm{C}$ measurements were carried out by the AMS method (Pelletron ${ }^{\mathrm{TM}}$ 5UD tandem van de Graaf, NEC Co.) at the Micro Analysis Laboratory, Tandem Accelerator (MALT) housed at the University of Tokyo. Descriptions of the equipment comprising the MALT system are presented by Matsuzaki et al. $(2004,2007)$. The ${ }^{14} \mathrm{C}$ precision is less than $\pm 5 \%$ ( $\left.1 \sigma\right)$ for measurements made using the MALT facility (Matsuzaki et al. 2004). Results of the ${ }^{14} \mathrm{C}$ analyses are reported as $\Delta^{14} \mathrm{C}$, as defined by Stuiver and Polach $(1977)$. The $\Delta{ }^{14} \mathrm{C}$ results are calculated from ${ }^{14} \mathrm{C} /{ }^{12} \mathrm{C}$ ratios; background and isotope fractionation effects for ${ }^{13} \mathrm{C}$ are corrected.

\section{RESULTS}

\section{Vertical Profile of CTD Data}

Water column profiles of salinity (S) and potential temperature $(\theta)$, observed using the CTD profiler, and T-S diagrams are presented in Figure 2 and Table 1. Water depth is calculated by water pressure based on Fofonoff and Millard (1983). The potential density anomaly $\left(\sigma_{\theta}\right)$ is calculated by salinity and potential temperature based on UNESCO (1981).

At station SY-S, the highest salinity value was observed at $\sim 200 \mathrm{~m}$ depth and the lowest salinity value (NPIW) was observed at $\sim 800 \mathrm{~m}$ depth (Figure $2 \mathrm{a}$ ). For August 2005 , the NPIW salinity value was higher than those measured during the other cruises (Figure 2a). Potential temperature decreased monotonically down to $1000 \mathrm{~m}$ depth, and the decrease was attenuated below $1000 \mathrm{~m}$ depth (Figure 2b). The upper limit of the thermocline was observed at $\sim 200 \mathrm{~m}$ depth (Figure $2 \mathrm{~b}$ ). The T-S diagram reveals that water properties varied at the sea surface and near $27 \sigma_{\theta}$, whereas they were largely unchanging at other depths (Figure 2c).

At station SY-N, the highest salinity value was observed at the sea surface and the lowest salinity value (NPIW) was observed near $400 \mathrm{~m}$ depth (Figure 2d). For August 2005, the vertical salinity profile varied at the depth of NPIW (Figure 2d). Potential temperature decreased monotonically down to $400 \mathrm{~m}$ depth, and decreased at a lower rate deeper than $400 \mathrm{~m}$ (Figure 2e). The upper limit of the thermocline was observed near the sea surface (Figure 2e). For August 2005, the potential temperature was lower than during other observations (Figure 2e). The T-S diagram shows that the water properties varied at the sea surface and near $27 \sigma_{\theta}$, whereas they were largely unchanging at other depths (Figure 2f).

\section{Vertical Profile of ${ }^{14} \mathrm{C}_{\mathrm{DIC}}$ Data}

Vertical profiles of $\Delta^{14} \mathrm{C}_{\mathrm{DIC}}$ measurements are presented in Figure 3 and Table 1. Average experimental error for all our $\Delta^{14} C_{\text {DIC }}$ measurements was $\pm 6 \%$ o $(1 \sigma)$. This is similar to the error reported by Matsuzaki et al. (2004), where the $\Delta^{14} \mathrm{C}$ precision was less than $\pm 5 \%$ o $(1 \sigma)$ for measurements made at the MALT facility. 

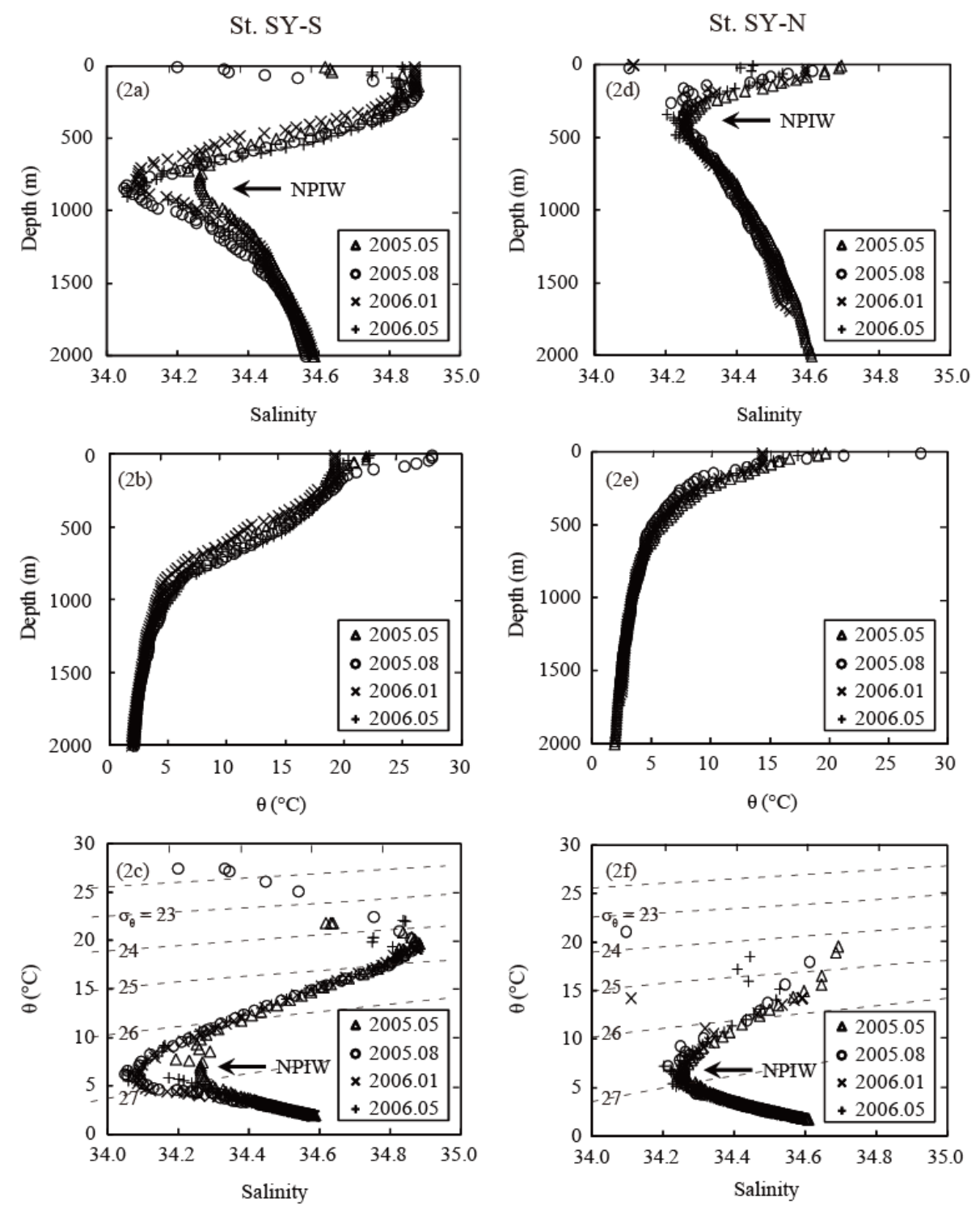

Figure 2 Water column profiles of salinity and potential temperature and diagrams of potential temperaturesalinity for stations SY-S (2a, 2b, and 2c, respectively) and SY-N (2d, 2e, and 2f, respectively).

The $\Delta^{14} \mathrm{C}_{\mathrm{DIC}}$ values for 200-2000 $\mathrm{m}$ depth from the samples collected in May 2005-May 2006 ranged from $-255 \%$ to $+65 \%$ at station SY-S and from $-266 \%$ to $-30 \%$ at station SY-N. The ${ }^{14} \mathrm{C}$ from the bomb tests (more than $0 \%$ ) was observed from 200 to $400 \mathrm{~m}$ depth at station SY-S, but was not observed at station SY-N (Figure 3). Therefore, bomb-produced ${ }^{14} \mathrm{C}$ penetrated greater depths at station SY-S and in the subtropical area, earlier than at station SY-N.

At station SY-S, $\Delta{ }^{14} \mathrm{C}_{\mathrm{DIC}}$ fluctuation was observed down to $1000 \mathrm{~m}$ (Figure $3 \mathrm{~b}$ ). The maximum fluctuation was observed near $600 \mathrm{~m}$ depth, with a variation of $\sim 100 \%$ (from $-56 \%$ to $+43 \%$, 17 times the $1 \sigma$ experimental error of $6 \%$ ). At $2000 \mathrm{~m}$ depth, the fluctuation range was about $20 \%$ (from $-255 \%$ to $-238 \%$, 3 times the $1 \sigma$ experimental error). 


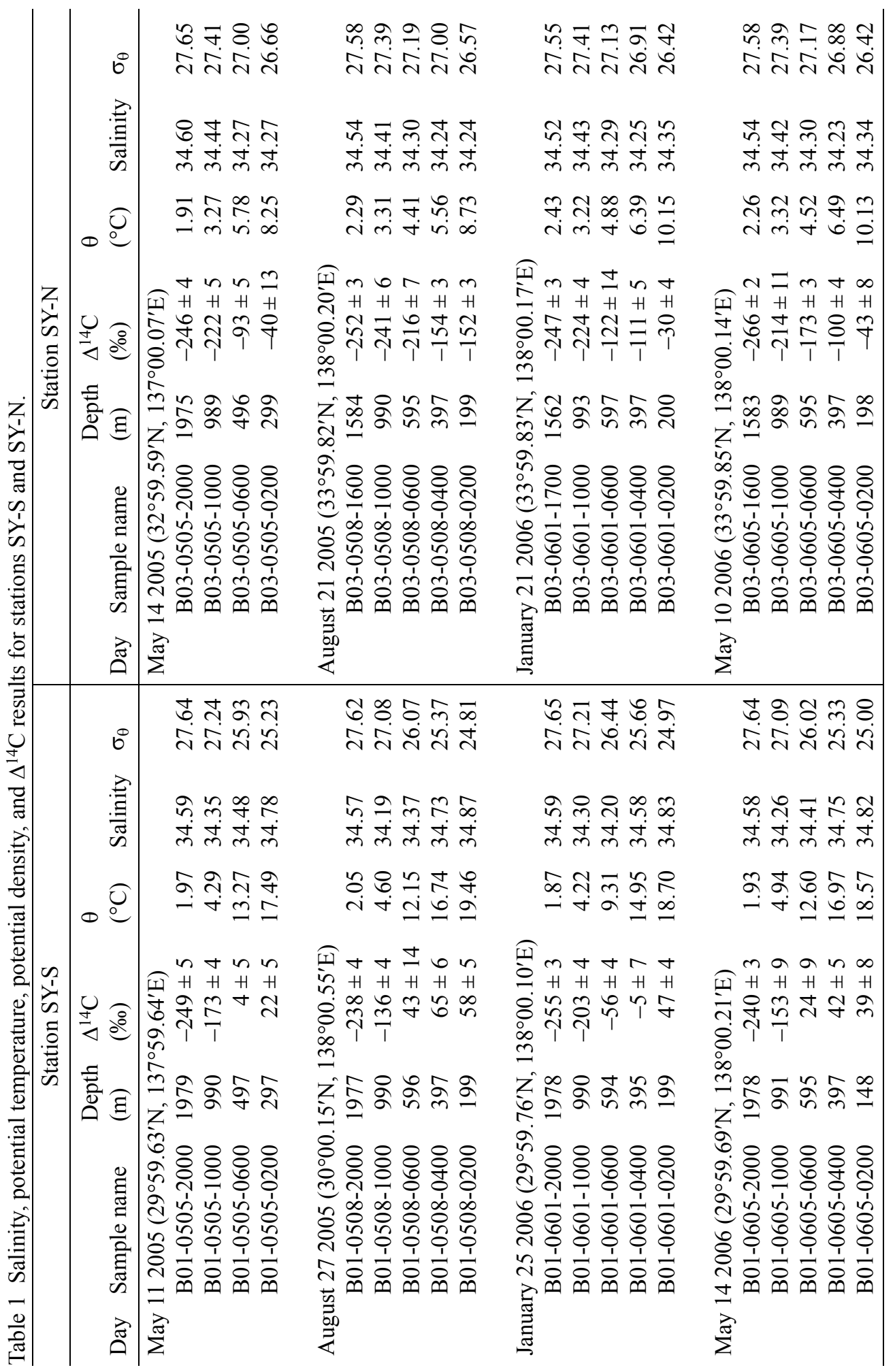



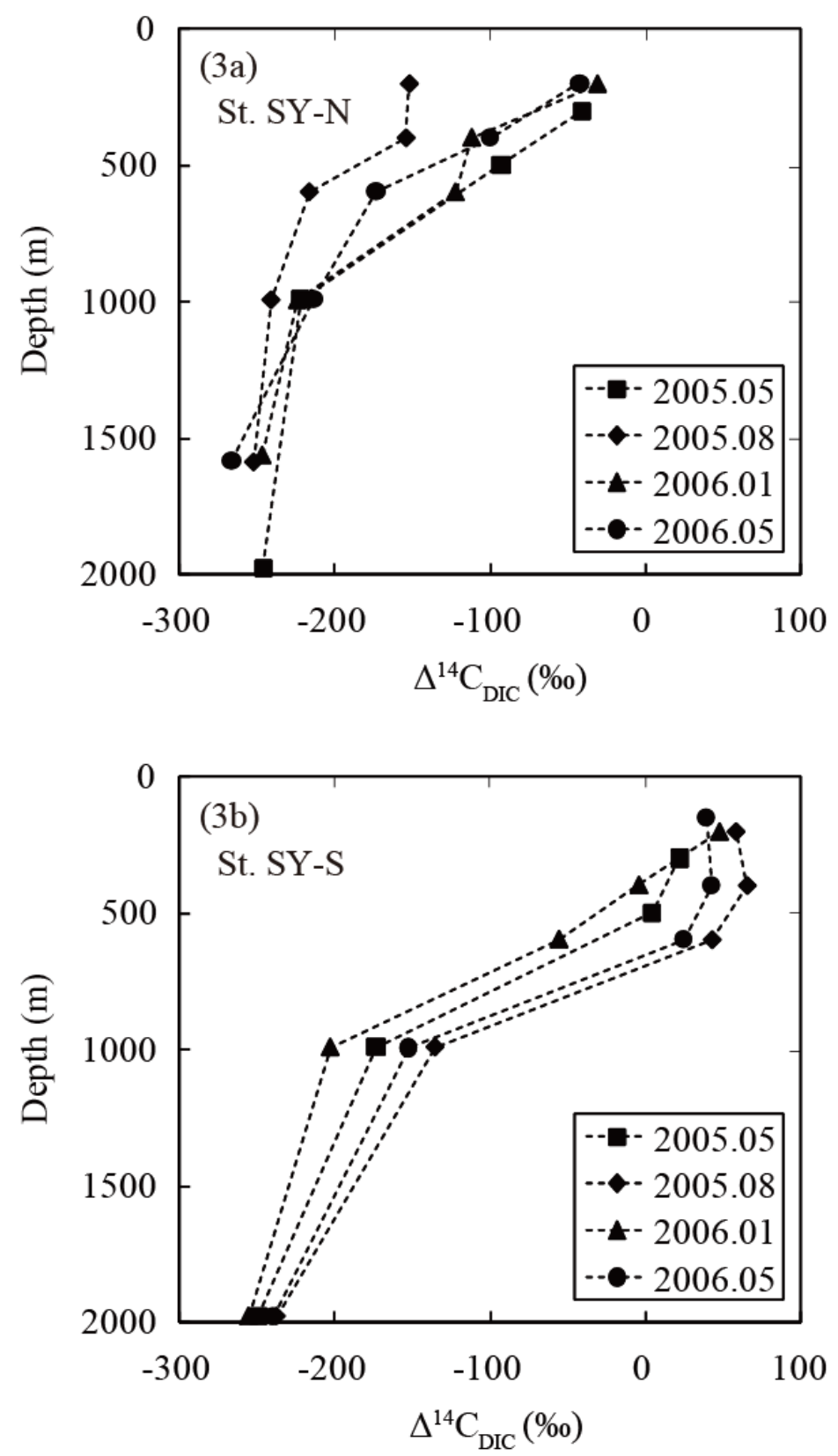

Figure 3 Water column profiles of $\Delta^{14} \mathrm{C}$ for stations SY-N (3a) and SY-S (3b)

At station SY-N, $\Delta{ }^{14} \mathrm{C}_{\mathrm{DIC}}$ fluctuation was observed down to $600 \mathrm{~m}$ (Figure 3a). The maximum fluctuation was observed near $600 \mathrm{~m}$ depth, with a variation of $\sim 125 \%$ o $(-216 \%$ to $-93 \%$, 21 times the $1 \sigma$ experimental error). At depths of 1000 and $2000 \mathrm{~m}$, the fluctuation ranges were $\sim 27 \%$ (from $-241 \%$ to $-214 \%$, 5 times the $1 \sigma$ experimental error) and $\sim 20 \%$ (from $-266 \%$ to $-246 \%$, 3 times the $1 \sigma$ experimental error), respectively. 
At depths of $200-600 \mathrm{~m}, \Delta^{14} \mathrm{C}_{\text {DIC }}$ values were lower and more varied at station SY-N. At $2000 \mathrm{~m}$ depth, both stations SY-S and SY-N had similar $\Delta{ }^{14} \mathrm{C}_{\text {DIC }}$ values (Figure 3). In addition, the $\Delta^{14} \mathrm{C}_{\text {DIC }}$ values were nearly constant from 1000 to $2000 \mathrm{~m}$ depth at station SY-N. On the other hand, the $\Delta^{14} \mathrm{C}_{\text {DIC }}$ values were larger and more variable at $1000 \mathrm{~m}$ than at $2000 \mathrm{~m}$ at station SY-S.

The $\Delta^{14} \mathrm{C}_{\mathrm{DIC}}$ water column profiles for January 2006 samples from both stations exhibit irregular trends with respect to the other 3 profiles due to the $\Delta^{14} \mathrm{C}_{\mathrm{DIC}}$ values for $200 \mathrm{~m}$ depth at station SY-S and $600 \mathrm{~m}$ depth at station SY-N. The $\Delta^{14} \mathrm{C}_{\text {DIC }}$ value for $200 \mathrm{~m}$ depth at station SY-S may result from vertical mixing down to $200 \mathrm{~m}$ depth during the winter (Figure $2 \mathrm{~b}$ ). The resulting $\Delta \Delta^{14} \mathrm{C}_{\mathrm{DIC}}$ value would thus increase due to the ${ }^{14} \mathrm{C}$ from surface waters. However, we cannot explain the $\Delta^{14} \mathrm{C}_{\text {DIC }}$ value for $600 \mathrm{~m}$ depth at station SY-N. The $\Delta^{14} \mathrm{C}_{\text {DIC }}$ value for $600 \mathrm{~m}$ depth at station SY-N is $\sim 50 \%$ higher than that of the smooth extended value. Sampling, $\mathrm{CO}_{2}$ gas extraction yield, and graphite preparation were all considered but ruled out as potential sources of the $\Delta^{14} \mathrm{C}_{\mathrm{DIC}}$ value for $600 \mathrm{~m}$ depth at station SY-N.

\section{DISCUSSION}

\section{Relationship between $\Delta^{14} \mathrm{C}_{\mathrm{DIC}}$ Values and CTD Data}

Dissolved inorganic carbon (DIC) is derived from the inorganic components exchanged with atmospheric $\mathrm{CO}_{2}$, oxidized organic matter, and mixing of different water masses. Therefore, seawater $\Delta^{14} \mathrm{C}_{\mathrm{DIC}}$ values vary water mass movement. Figure 4 shows the relationship between the $\Delta^{14} \mathrm{C}_{\mathrm{DIC}}$ value and CTD data.

Salinity decreases from the surface water to NPIW and then increases in deep waters (Figure 2a, 2d). The relationship between $\Delta^{14} \mathrm{C}_{\mathrm{DIC}}$ values and salinity shows a $\mathrm{V}$-shape, where the minimum salinity value occurs at a $\Delta^{14} \mathrm{C}_{\text {DIC }}$ value of about $-100 \%$ for both stations (Figure $4 \mathrm{a}$ ). Four data points from station SY-N with $\Delta^{14} \mathrm{C}_{\text {DIC }}$ values of $-100 \%$ exhibit a shallow V-shape attributed to mixing with NPIW and water of another origin.

Potential temperature exhibits a positive correlation with $\Delta^{14} \mathrm{C}_{\mathrm{DIC}}$ values (Figure $4 \mathrm{~b}$ ). The upper limit of the thermocline was observed near $200 \mathrm{~m}$ depth at station SY-S (Figure 2b). However, that of SY-N was observed near the sea surface (Figure 2e). Thus, the $\Delta^{14} \mathrm{C}_{\text {DIC }}$ water column profiles are associated with that of the potential temperature, at least in the case of the study region.

According to Reid (1965), the core depth of NPIW exists at $26.8 \sigma_{\theta}$. Therefore, we suggest the existence of 3 major end components for ${ }^{14} \mathrm{C}_{\mathrm{DIC}}$ in the study region: 1) surface water; 2) NPIW; and 3) North Pacific Deep Water (NPDW; deep circulation water). If only 2 end components (surface water and NPDW) existed, the $\sigma_{\theta}-\Delta^{14} \mathrm{C}_{\text {DIC }}$ plot would be a straight line. The $\sigma_{\theta}-\Delta^{14} \mathrm{C}_{\text {DIC }}$ plot has a boundary near $26.7 \sigma_{\theta}$ (Figure $4 \mathrm{c}$ ), which is close to the value of NPIW. Thus, it is possible that NPIW contributes to increasing $\Delta{ }^{14} \mathrm{C}_{\mathrm{DIC}}$ values at intermediate depths.

\section{Upwelling at Station SY-N}

Between July 2004 and August 2005, the Kuroshio formed a large meander (LM) flow pattern (Yoshida et al. 2006; Sugisaki et al. 2010), where a mesoscale cold eddy appeared around the northward Kuroshio flow. In August 2005, the end of the LM term, the water column $\Delta^{14} \mathrm{C}_{\mathrm{DIC}}$ profile values was smaller than those of the other 3 profiles for station SY-N (Figure 3a). The $\Delta^{14} \mathrm{C}_{\text {DIC }}$ values exhibited a constant value of about $-150 \%$ at 200 and $400 \mathrm{~m}$ depth. We suggest upwelling of deeper waters at station SY-N as the source of these low $\Delta^{14} \mathrm{C}_{\mathrm{DIC}}$ values. When deeper water is supplied to the surface by upwelling, the $\Delta^{14} \mathrm{C}_{\mathrm{DIC}}$ value decreases in the sea surface, because the DIC in deep water has a relatively low $\Delta^{14} \mathrm{C}_{\mathrm{DIC}}$ value. 

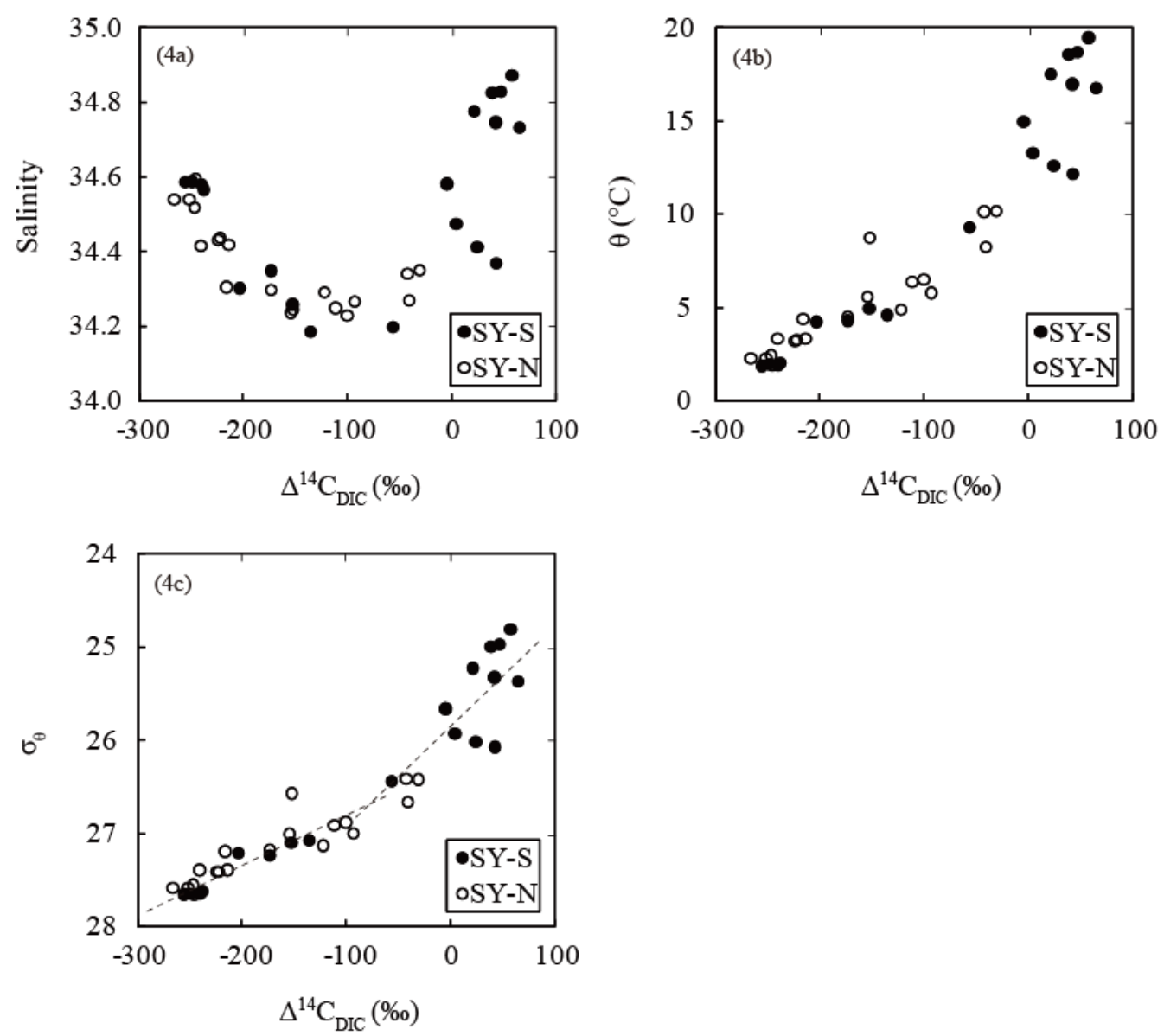

Figure 4 Salinity (4a), potential temperature (4b), and potential density anomaly (4c) versus $\Delta^{14} \mathrm{C}$ for all data

The $\Delta{ }^{14} \mathrm{C}_{\mathrm{DIC}}$ values of August 2005 samples suggest that low $\Delta{ }^{14} \mathrm{C}_{\mathrm{DIC}}$ value deep water was supplied to the sea surface. If deep water from between 1000 and $2000 \mathrm{~m}$ depth $\left(\Delta^{14} \mathrm{C}_{\mathrm{DIC}}=-250 \%\right)$ was supplied to the sea surface only by upwelling, the mixing ratio of deep water would be $50 \%$ or more at $200 \mathrm{~m}$ depth $\left(\Delta^{14} \mathrm{C}_{\mathrm{DIC}}=-40 \%\right.$ at $200 \mathrm{~m}$ depth, $\Delta{ }^{14} \mathrm{C}_{\mathrm{DIC}}=-150 \%$ at $200 \mathrm{~m}$ depth for August 2005), by mass balance calculation. Due to the complex mixing processes of seawater, it is difficult to understand the effect of upwelling only using $\Delta^{14} \mathrm{C}_{\mathrm{DIC}}$ values. As a result, a more elaborate discussion is required to explain the relationship between $\Delta^{14} \mathrm{C}_{\mathrm{DIC}}$ values and physical and chemical oceanographic data. This detailed discussion will appear in another paper.

\section{Comparison with GEOSECS Data}

Estimation of upwelling rates using bomb-produced ${ }^{14} \mathrm{C}$ has been primarily carried out in the Arabian Sea (e.g. Bhushan et al. 2008). We need their methods to compare our results with those from GEOSECS station $224\left(34^{\circ} 15^{\prime} \mathrm{N}, 141^{\circ} 58^{\prime} \mathrm{E}\right.$; Östlund and Stuiver 1980) and to estimate the penetration of bomb-produced ${ }^{14} \mathrm{C}$.

The seawater samples from GEOSECS station 224 were collected in October 1973 (Östlund and Stuiver 1980). In this period, the Kuroshio flowed in the NLM pattern (Yoshida et al. 2006; Sugisaki 
et al. 2010) and northward from GEOSECS station 224. In addition, the T-S diagram at GEOSECS station 224 shown in Östlund and Stuiver (1980) is similar to the profile for station SY-S (high-salinity layer at the sea surface and low-salinity layer at the depth of $26.8 \sigma_{\theta}$ ). Thus, we decided to compare the $\Delta{ }^{14} \mathrm{C}_{\text {DIC }}$ vertical profile at station SY-S with that from GEOSECS station 224.

Figure 5 shows the average $\Delta^{14} \mathrm{C}_{\mathrm{DIC}}$ vertical profiles for station SY-S overlain on that of station 224 . Over the $\sim 30$-yr period between the GEOSECS Pacific expedition and our study, $\Delta{ }^{14} \mathrm{C}_{\mathrm{DIC}}$ values for seawater at surface layer decreased as much as $100 \%$, whereas seawater below $600 \mathrm{~m}$ depth has similar profiles.

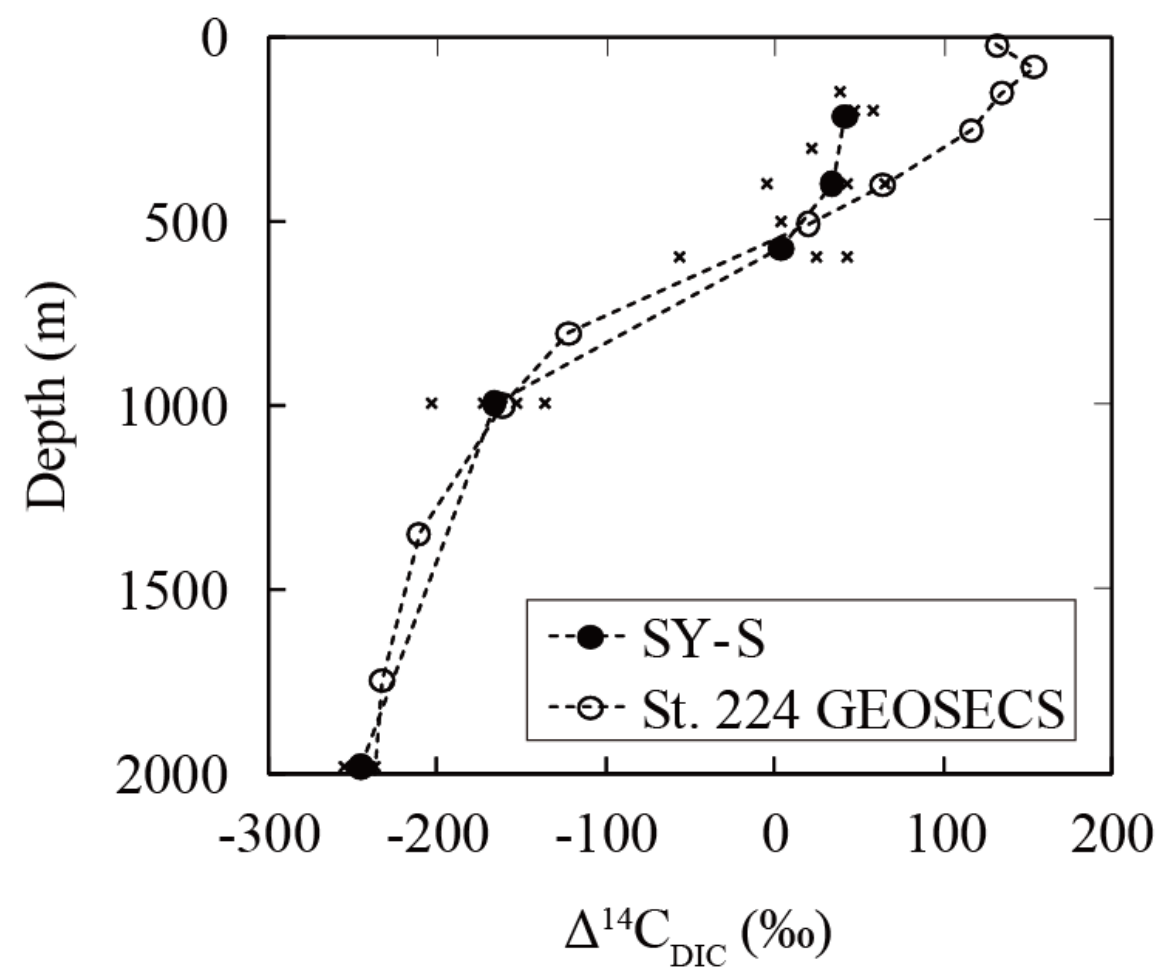

Figure 5 Water column profiles of $\Delta^{14} \mathrm{C}$ for stations SY-S and GEOSECS station 224 (Östlund and Stuiver 1980). For station SY-S, black crosses and black circles identify individual $\Delta^{14} \mathrm{C}$ measurements and the average $\Delta^{14} \mathrm{C}$ values for each depth, respectively. For GEOSECS station 224, open circles identify $\Delta^{14} \mathrm{C}$ values.

The $\Delta{ }^{14} \mathrm{C}_{\mathrm{DIC}}$ vertical profiles of several studies found that the $\Delta^{14} \mathrm{C}_{\mathrm{DIC}}$ value decreases in the surface layer and then increases in the deeper ocean by diffusion for the last few decades. However, our data does not show such an increase in the deeper ocean and is also highly varied at intermediate depths (near 600 and $1000 \mathrm{~m}$ ) (Figure 5). We then need to explain the similar profile down to $2000 \mathrm{~m}$. We suggest upwelling as the most likely source at intermediate depth. Strong upwelling occurs in the northern portion of the study area, including at station SY-N, during the Kuroshio LM. Thus, the $\Delta^{14} \mathrm{C}_{\text {DIC }}$ value is expected to decrease in the surface and intermediate layers of the northern Kuroshio region. If this water, which has a low $\Delta^{14} \mathrm{C}_{\mathrm{DIC}}$ value, flows to the southern Kuroshio region, the $\Delta{ }^{14} C_{\text {DIC }}$ value of intermediate layers will decrease. 
Kumamoto et al. (2002) and Povinec et al. (2004) reported bomb-produced ${ }^{14} \mathrm{C}$ penetration in the intermediate layer of the subtropical area including station SY-S of this study. This mechanism may cause an increase in $\Delta^{14} \mathrm{C}_{\text {DIC }}$ values at the intermediate layer. On the other hand, upwelling during the Kuroshio LM causes a decrease in $\Delta^{14} \mathrm{C}_{\mathrm{DIC}}$ value at the surface and intermediate layer. Thus, our data suggest that upwelling caused by the Kuroshio LM has a strong influence on the $\Delta^{14} \mathrm{C}_{\mathrm{DIC}}$ water column profiles in the study region.

\section{CONCLUSION}

We report the dissolved inorganic radiocarbon $\left({ }^{14} \mathrm{C}_{\mathrm{DIC}}\right.$ ) water column profiles (down to $2000 \mathrm{~m}$ depth) in the Kuroshio region, offshore of the southern Japanese coast, for sampling between 2005 and 2006. Because the Kuroshio flow pattern changed to the Kuroshio LM between July 2004 and August 2005, the $\Delta^{14} \mathrm{C}_{\text {DIC }}$ water column profiles include those of the LM term of Kuroshio (May 2005 and August 2005). These profiles suggest that upwelling associated with the Kuroshio LM has a strong influence on the $\Delta^{14} \mathrm{C}_{\mathrm{DIC}}$ water column profiles in the study region. The main findings of our study are the following:

1. The largest fluctuation was observed for the intermediate layer ( $\sim 600 \mathrm{~m}$ depth), ranging from $\sim 100 \%$ at station SY-S to $\sim 125 \%$ at Station SY-N. In contrast, the fluctuation observed at $2000 \mathrm{~m}$ depth at both stations SY-S and SY-N was much smaller, $\sim 20 \%$.

2. The $\Delta{ }^{14} C_{\text {DIC }}$ values have a negative correlation with potential density anomaly. The $\sigma_{\theta}-\Delta^{14} C_{\text {DIC }}$ plot has a boundary near $26.7 \sigma_{\theta}$, which is close to the value for NPIW. Thus, it is possible that NPIW is at least in part responsible for the increased $\Delta^{14} C_{\text {DIC }}$ values at intermediate depths.

3. The water column $\Delta{ }^{14} \mathrm{C}_{\mathrm{DIC}}$ profile values from the August 2005 sampling during the waning stage of Kuroshio LM (-150\% at $200 \mathrm{~m}$ and $400 \mathrm{~m}$ depth) are smaller than those of the 3 other profiles from station SY-N. There was a large change in the values between May 2005 and August 2005.

4. Over the $\sim 30$-yr period between the GEOSECS Pacific expedition and the present study, the $\Delta{ }^{14} \mathrm{C}_{\mathrm{DIC}}$ values decreased down to $600 \mathrm{~m}$ depth and follow the same trend below $600 \mathrm{~m}$ depth. We suggest that upwelling is the cause for this difference.

\section{ACKNOWLEDGMENTS}

We thank the captain and crew of the R/V Soyo-Maru for their cooperation and support during the cruises. We are grateful to Satish-Kumar Madhusoodhan, Kazumasa Oguri, Masashi Tsuchiya, and Yoshimi Suzuki for helpful discussions and reviews of this manuscript. We thank the MALT staff for the AMS ${ }^{14} \mathrm{C}$ measurements using the accelerator mass spectrometer housed at the University of Tokyo. We thank Kentaro Mori and Keita Okuda for performing the extractions of $\mathrm{CO}_{2}$ gas and the ${ }^{14} \mathrm{C}$ analyses. We would also like to thank the 2 anonymous reviewers. The R/V Soyo-Maru cruises were supported by funds from the Agriculture, Forestry and Fisheries Research Council (Japan) through the "Research Project on the Global Warming Effect to Agriculture, Forestry and Fisheries."

\section{REFERENCES}

Aramaki T, Mizushima T, Kuji T, Povinec PP, Togawa O. 2001. Distribution of radiocarbon in the southwestern North Pacific. Radiocarbon 43(2B):857-67.

Bard E, Arnold M, Toggweiler R, Maurice P, Duplessy JC. 1989 . Bomb ${ }^{14} \mathrm{C}$ in the Indian Ocean measured by accelerator mass spectrometry: oceanographic implications. Radiocarbon 31(3):510-22.
Bhushan R, Somayajulu BLK, Chakraborty S, Krishnaswami S. 2000. Radiocarbon in the Arabian Sea water column: temporal variations in bomb ${ }^{14} \mathrm{C}$ since the GEOSECS and $\mathrm{CO}_{2}$ air-sea exchange rates. Journal of Geophysical Research 105(C6):14,273-82.

Bhushan R, Dutta K, Mulsow S, Povinec PP, Somayajulu BLK. 2003. Distribution of natural and man-made ra- 
dionuclides during reoccupation of GEOSECS stations 413 and 416 in the Arabian Sea: temporal changes. Deep-Sea Research II 50(17-21):2777-84.

Bhushan R, Dutta K, Somayajulu BLK. 2008. Estimates of upwelling rates in the Arabian Sea and the equatorial Indian Ocean based on bomb radiocarbon. Journal of Environmental Radioactivity 99(10):1566-71.

Broecker WS. 1987. The biggest chill. Natural History Magazine 96:74-82.

Broecker WS, Peng TH, Stuiver M. 1978. An estimate of the upwelling rate in the equatorial Atlantic based on the distribution of bomb radiocarbon. Journal of Geophysical Research 83(C12):6179-86.

CCHDO. 2011. CLIVAR and Carbon Hydrographic Data Office. URL: http://cchdo.ucsd.edu/. Accessed 17 June 2011

Druffel ERM, Bauer JE, Griffin S, Beaupré SR, Hwang J. 2008. Dissolved inorganic radiocarbon in the North Pacific Ocean and Sargasso Sea. Deep-Sea Research I 55(4):451-9.

Fofonoff NP, Millard Jr RC. 1983. Algorithms for Computation of Fundamental Properties of Seawater. Paris: UNESCO Technical Papers in Marine Science 44. $53 \mathrm{p}$.

Horibe Y, Gamo T. 1980. Chemical characteristics of the Cold Water Mass of Kuroshio. In: The Kuroshio IV: Proceenings of the 4th CSK Symposium. Tokyo: Saikon Publishing Co. Ltd. p 360-70.

Kawabe M. 1985. Sea level variations at the Izu Islands and typical stable paths of the Kuroshio. Journal of Oceanography 41(5):307-26.

Kawabe M. 1995. Variations of current path, velocity, and volume transport of the Kuroshio in relation with the large meander. Journal of Physical Oceanography 25(12):3103-17.

Kawabe M. 2005. Variations of the Kuroshio in the southern region of Japan: conditions for large meander of the Kuroshio. Journal of Oceanography 61(3):52937.

Kitagawa H, Masuzawa T, Nakamura T, Matsumoto E. 1993. A batch preparation method for graphite targets with low background for AMS ${ }^{14} \mathrm{C}$ measurements. $R a$ diocarbon 35(2):295-300.

Kumamoto Y, Murata A, Saito C, Honda M, Kusakabe M. 2002. Bomb radiocarbon invasion into the northwestern North Pacific. Deep-Sea Research II 49(2425):5339-51.

Matsuzaki H, Nakano C, Yamashita H, Maejima Y, Miyairi Y, Wakasa S, Horiuchi K. 2004. Current status and future direction of MALT, the University of Tokyo. Nuclear Instruments and Methods in Physics Research B 223-224:92-9.

Matsuzaki H, Nakano C, Tsuchiya Y, Kato K, Maejima Y,
Miyairi Y, Wakasa S, Aze T. 2007. Multi-nuclide AMS performances at MALT. Nuclear Instruments and Methods in Physics Research B 259(1):36-40.

Östlund HG, Stuiver M. 1980. GEOSECS Pacific radiocarbon. Radiocarbon 22(1):25-53.

Povinec PP, Aramaki T, Jull AJT, Kwong LLW. 2004. Radiocarbon in the water column of the southwestern North Pacific Ocean-24 years after GEOSECS. Radiocarbon 46(2):583-94.

Reid JL. 1965. Intermediate Waters of the Pacific Ocean. Baltimore: Johns Hopkins Oceanographic Studies 2. $85 \mathrm{p}$.

Somayajulu BLK, Bhushan R, Narvekar PV. 1999. $\Delta{ }^{14}$ C, $\Sigma \mathrm{CO}_{2}$ and salinity of the western Indian Ocean deep waters: spatial and temporal variations. Geophysical Research Letters 26(18):2869-72.

Stommel H, Yoshida K. 1972. The Kuroshio - Its Physical Aspects. Tokyo: University of Tokyo Press. p 235354.

Stuiver M, Polach HA. 1977. Discussion: reporting of ${ }^{14} \mathrm{C}$ data. Radiocarbon 19(3):355-63.

Stuiver M, Quay PD, Östlund HG. 1983. Abyssal water carbon-14 distribution and the age of the world oceans. Science 219(4586):849-51.

Stuiver M, Östlund HG, Key RM, Reimer PJ. 1996. Large volume WOCE radiocarbon sampling in the Pacific Ocean. Radiocarbon 38(3):519-61.

Sugisaki H, Nonaka M, Ishizaki S, Hidaka K, Kameda T, Hirota Y, Oozeki Y, Kubota H, Takasuka A. 2010. Status and trends of the Kuroshio region, 2003-2008. In: McKinnell SM, Dagg MJ, editors. Marine Ecosystems of the North Pacific Ocean, 2003-2008. PICES Special Publication 4. North Pacific Marine Science Organization, Sidney, British Columbia. p 330-59.

Talley LD. 1993. Distribution and formation of North Pacific Intermediate Water. Journal of Physical Oceanography 23(3):517-37.

Tsuchiya R, Wada H. 2002. Vacuum $\mathrm{CO}_{2}$ extraction method from seawater for AMS ${ }^{14} \mathrm{C}$ analysis. Geoscience Reports Shizuoka University 29:113-8. In Japanese.

UNESCO. 1981. Background Papers and Supporting Data on the International Equation of State of Seawater. Paris: UNESCO Technical Papers in Marine Science $38.192 \mathrm{p}$.

Yoshida T, Shimohira Y, Rinno H, Yokouchi K, Akiyama H. 2006. Criteria for the determination of a large meander of the Kuroshio based on its path information. The Oceanography in Japan 15(6):499-507. In Japanese.

You Y. 2003. The pathway and circulation of North Pacific Intermediate Water. Geophysical Research Letters 30(24):2291, doi:10.1029/2003GL018561. 